\title{
Examining the Correlation between Excessive Recreational Smartphone Use and Academic Performance Outcomes
}

\author{
Shawn De Shields \\ Bermuda College \\ Cordell W. Riley \\ Bermuda College
}

The purpose of this study is to ascertain whether excessive recreational smartphone use significantly affects students' academic performance outcomes, study patterns, learning abilities and interactions with fellow students and faculty. Data was collected from 257 students attending a small community college in Bermuda to identify if there is a direct correlation between the grade point averages of participants and excessive recreational time spent on their smartphones. This study will also highlight creative technology-based learning platforms and productive strategies that can assist faculty with converting excessive recreational smartphone use into productive and engaging learning opportunities.

\section{INTRODUCTION}

Contrary to popular belief, Bermuda is not located in the Caribbean region. These 150 islands are situated in the Atlantic Ocean, roughly 774 miles northeast of New York City. Approximately 65,000 residents inhabit Bermuda's tropical landscape and the sophisticated microstate's economic stability is primarily due to the thriving insurance and captive insurance sectors. However, prior to the 1990s tourism was responsible for sustaining Bermuda's economy due to the island's upscale hotels, famous beaches and welcoming residents. The only tertiary institute on the island is the Bermuda College.

In 2024 the Bermuda College will celebrate 50 years of providing higher education to the citizens of Britain's oldest dependent territory. As the only institution of higher learning within a thousand mile radius it has its privileges, challenges and opportunities. Discovering ways to stay abreast of an ongoing technology tsunami will require agility, and foresight. Moreover, successfully navigating in this digitally infused 21 st-century society requires the adaptation of innovative technology-based learning platforms, which are designed to not only fully engage students but also meet the changing learning need of digital natives.

Steve Jobs put it best when he said, "Every once in a while, a revolutionary product comes along that changes everything" (Jobs, 2007). It goes without question that smartphones are indeed revolutionary. The technologies required to make them functional and dependable will continue to have a significant impact on educational norms, which are ripe for disruption and an infusion of innovation. 
Smartphones did not appear magically, they were strategically created and programmed by some of the world's best engineers to not only manipulate users but also to be extremely persuasive. These observations were made by Tristan Harris a former Google product manager.

Have you ever noticed how our smartphones reward us when we give them some attention? This is certainly not accidental but an ingenious design feature that all smartphones have. For example, with a just few clicks the Internet appears on our smartphones and we are transformed into a completely new world of information overload. Instantaneously the attention span or our students has been kidnapped by a powerful device, which has cleverly convinced them to always keep these devices within eyeshot so that they consistently remain connected to the virtual world. This behavior usually tends to distract people, and in particular students who would benefit from what is being taught in their classrooms.

The swift popularity of smartphone devices has forced higher education institutions to grapple with a formidable shift in the teaching and learning process. Omnipresent smartphones are now an essential part of modern societal norms. To the point where most students, and on occasion faculty, are unable to effectively function without their multifaceted handheld devices.

Smartphones can be considered as, "the gift that keeps on giving", or akin to junk food. Both are difficult to discontinue having a craving for, even though we know that too much of it is not good for us. This significant smartphone dependency or love affair with smartphones equates to addictive tendencies. An addiction can be defined as the continuous pursuit of something, despite achieving negative outcomes.

Extensive research is available describing how this revolutionary handheld device has forever changed the way people think, communicate, learn, spend time and even interact with each other. Smartphones and the Internet have also completely transformed the way people acquire goods and services. For example, online shopping conglomerates such as Amazon and eBay have made shopping easy and convenient via smartphone apps. Pressed for time like most of us? Just use your smartphone to preorder all your weekly groceries online and drive by the Walmart Express pick-up area to collect when ready. Conversely, there is limited research which concludes if there is a direct correlation between excessive recreational smartphone use and the learning experiences of students. For example, what impact does excessive recreational smartphone use have on student's study patterns, grades, learning capabilities and direct interactions with fellow students and faculty?

\section{REVIEW OF LITERATURE}

Smartphone dependability has become pervasive for most students as they are usually using their smartphones for communication and/or recreational activities. To paraphrase Mark Twain "Don't let your studies interfere with your education," puts things into context. Consequently, are institutions of higher learning strategically transforming themselves to take advantage of and embrace this smartphone dependency epidemic? Those that do will most likely have an increase in enrollment. However, those that do not will most likely vanish.

Connectivity is now essential as many students feel the need to always stay "connected" with their friends, family and, in many cases, their teachers. Not being able to consistently dwell in one or several virtual social networking communities often creates unwanted anxiety and the feeling of being disconnected from the mainstream. Frequently glancing at smartphones while riding elevators, attending classes, walking on campus, sitting on flights, commuting on trains or metro lines, standing at intersections waiting to cross, or even waiting in line at Starbucks is common practice for most. Reaching for our smartphones as soon as we wake-up in the morning, before we go sleep at night or during private moments in the bathroom have become second nature.

A unique philosophy about addictive tendencies was depicted by Norman Doidge, a Canadian psychiatrist who concluded that, "Addicts show a loss of control of the activity, compulsively seek it out despite negative consequences, develop tolerance so that they need higher and higher levels of stimulation for satisfaction, and experience withdrawal if they can't consummate the addictive act." (Doidge, 2007). 
Many restaurant tables have been converted into smartphone hubs during peak operational hours. Absence of any verbal communication has become the norm. Usually, excessive smartphone activity occurs throughout the dining experience and patron's devices all seem to be repeating those famous Tupac Shakur lyrics, "All eyes on me."

Research by Pirani and Sheehan as cited by Kim, IIon and Altmann, indicated that, "digital natives," those who grew up in the digital technology era, often consider smartphones as one of their preferred learning tools. "Students are plugged in and communicating constantly," (Kim, IIon and Altmann, 2013). In many cases this also applies to faculty. According to a May 31, 2018 Pew Research Center report, "Some 95\% of teens now say they have or have access to a smartphone, which represents a 22\% increase from the 73\% of teens who said this in 2014-2015." More alarming is that this same report noted how, "Some 45\% of teens say they use the internet almost constantly, a figure that has nearly doubled from 24\% who said the same thing in the 2014-2015 survey." (Pew Research Center, 2018).

Over the next decade the logical expectation is that a much higher percentage of Generation $\mathrm{X}, \mathrm{Y}$ and Z students will most likely be "habitually" online. Consequently, institutions of higher learning must understand that smartphones are not only directly affecting how students learn but also forever changing the trajectory of longstanding "chalk and talk" teaching practices. Such transformational change from the analog to a digital learning space must be accompanied with reformed teaching methods that are aligned with the radical changes associated with the arrival of smartphones and how students use them.

A study looking at the relationship between cellphone and academic performance by Lepp, Barkley and Karpinski found that, "cellphone use may disrupt behaviors conducive to academic success." (Lepp, Barkley and Karpinski, 2013) Findings from a study conducted by Andrew Lepp, Ph.D., of Kent State University noted that, frequent cellphone usage by college students "was negatively related to GPA and positively related to anxiety" (Lepp, 2013). Additionally, this study concluded that excessive daily smartphone users tended to have lower grades, higher anxiety levels and lower satisfaction with life (happiness) relative to their college peers who spent less time on their smartphones.

Research by Pirani and Sheehan concluded that the majority or $85 \%$ or university leaders in the U.S. are convinced about how eventually Web-accessible and/or portable devices such as smartphones would be crucial in higher education. (Pirani and Sheehan, 2009). A study by Roach established that it would be advisable for institutions of higher learning to adopt smartphones as an effective campus-wide learning tool. Roach also noted that electronic devices would most likely become the preferred delivery option by university students in the future. (Roach, 2010)

New York University Professor Dr. Donna Quadri delineated at her Foundations of Effective Technology Integration: Best Practices in teaching workshop, "If you are not using technology to teach you should be, and technology should be used as an attraction not a distraction" (Quadri, 2013).

A study discussing the implementation of seven technology best practices supports the aforementioned notion when concluding that, "Technologies can help students learn in ways they find most effective and broaden their repertoires for learning." (Chickering \& Ehrmann, 1996) These authors are also conceded that, technology used in the classroom, "can strengthen faculty interaction with all students, but especially with shy students who are reluctant to ask questions or challenge the teacher directly." (Chickering \& Ehrmann, 1996)

Furthermore, research by Zellweger as cited by Aldunate and Nussbaum supports how, "faculties who commit to more time integrating educational technology into their teaching have a greater chance of adopting new technologies." A creative writing teacher and Pepperdine University doctoral student denoted that, "the most successful teachers are putting lessons into a context that ensures students their real value in the real world, and that often requires additional effort to learn technologies that they have already mastered." (Rudi, 2011) This same author is also convinced that, "purpose-driven learning has much more promise with today's "what's in it for me?" students, who typically don't respond to the concept of learning for its own sake." (Rudi, 2011) When investigating how technology supports learning, a study by Martinez concluded that, student learning can be enhanced with the use of programs and applications in a number of different ways. However, she also cautioned about making technology the "servant not the master." (Martinez, 2014) 
Previous research by one of this paper's authors examined the impacts of technology being used in classrooms at the Bermuda College. Out of the 237 students who participated in that study, 140 or $59 \%$ indicated that they preferred attending classes where lecturers used more technology rather than those who used less to deliver the course content. A majority of students confirmed that different forms of technology used by faculty in the classroom played an important role in improving their learning experience as $46.1 \%$ or 108 agreed and 69 or $29.5 \%$ strongly agreed with this premise. Conversely, only $2.1 \%$ or 5 students noted that this was not the case. Over three quarters or $85 \%$ of respondents believed that using more technology in the classroom in general will most likely play a pivotal role in transforming education in the 21 st century. (De Shields, 2016)

A thought-provoking article entitled, "Have Smartphones Destroyed a Generation," by psychologist Jean Twenge noted that, "the arrival of the smartphone has radically changed every aspect of teenagers" lives, from the nature of their social interactions to their mental health."

A 2017 New York Times article by Matt Richtel explores whether teenagers are, "using drugs less in part because they are constantly stimulated and entertained by their computers and phones." (Richtel, 2017). Research by Lepp, Barkley and Karpinski emphasized that a need exists for faculty to better understand how smartphones can be used to make a genuine contribution to the student learning process.

A descriptive study analyzing how 109 Iranian dental students used their smartphones for learning purposes concluded that, "the learning purposes or combining traditional educational approaches and eteaching methods, including smartphones, can provide students with more diverse learning opportunities." (Shooriabi, M., \& Gilavand, A. 2017). Worth mentioning is how "96\% of these dental students use their smartphones and the Internet to search required educational texts, $94 \%$ use it to share their notes with classmates, $94 \%$ use it to take pictures of their work in university, $93 \%$ use it to make a video of their works in university, and $92 \%$ used their smartphones for other educational purposes, not indicated in this study." (Shooriabi, M., \& Gilavand, A. 2017).

A recent online article titled "How Technology is Taking Higher Education Learning Spaces to New Heights," produced by the Next Generation Learning Spaces contingent argues that, "the time for higher education learning spaces to invest in technology is now. Tech-savvy students are entering colleges and universities with more self-taught knowledge than ever before. Having grown up in the digital age, millennials and Gen Z'ers are not only looking for schools that meet their technological capabilities they're demanding it." (Next Generation Learning Spaces, 2019)

When discussing the significance and relevance of teaching with smartphones in higher education Odem mentioned how, "The world has gone mobile. Smartphones are here to stay. They are in our classrooms. It is essential that educators continue to explore effective uses of smartphones in the classroom." (Odem, 2016)

A reflective study by Halaweh observed how students behaved when using smartphones spontaneously during class in a university in Dubai. The author concluded that smartphones are constantly being used by students "to directly or indirectly support and enhance personal learning. Therefore, universities policies' and the instructors' teaching tools and methods must be adapted to correspond with mobile technology advancement and the widespread use of smartphones." (Halaweh, 2017) Furthermore, Halaweh delineated that, 'the current policies are old, having been set in arena when the mobile phone was simply a device for making phone calls and sending text messages. Indeed, university policy-makers should formulate policies to regulate, not prevent, the usage of mobile phones in the classroom." (Halaweh, 2017)

Research examining how active learning affects the academic outcomes of science, engineering and mathematics students concluded that, "the average examination scores improved by about 6\% in active learning sections, and that students in classes with traditional lecturing were 1.5 times more likely to fail than students in classes with active learning."(Freeman, Eddy, McDonough, Smith, Okoroafor, Jordt \& Wenderoth, 2014) When assessing the link between excessive in class smartphone usage and "smarts in the classroom," Barkley presumed that active learning occurs "when the mind is actively engaged. Its defining characteristic is that students are dynamic participants in their learning and that they are reflecting on and monitoring both the process and the results of their learning." (Barkley, 2010) 
Appealing to the diverse learning needs of Generation $\mathrm{X}, \mathrm{Y}$, and $\mathrm{Z}$ students, who are noticeably "attached at the hip" with their smartphones will require faculty to discover ways of integrating immersive technology solutions into their teaching techniques. Immersive technologies such as augmented, virtual and mixed reality platforms are becoming mainstream and will continue to shift the learning experience away from traditional delivery methods. Confucius said it best, "Tell me, and I will forget. Show me, and I may remember. Immerse me, and I will understand." (Confucius, 450BC)

An Inside Higher ED online article entitled, "Students are Using Mobile Even if You Aren't" discusses how "Smartphones and tablets are changing how teachers teach and how students learn." (Lieberman, 2017). Data from an Educause study established that one third of the 44,000 students surveyed used smartphones in classroom to, "make other connections with material." This article also highlights how Professor of Philosophy Megan Sullivan from the University of Notre Dame is a proponent of in class smartphone usage and contends that, "Finding ways to meet [students] halfway, using what feels normal for them and feels exciting can make your teaching that much more effective, rather than sticking your head in the sand, " (Lieberman, 2017)

\section{METHODOLOGY}

Twenty of the thirty-eight full time Bermuda College faculty were randomly selected to participate in this study. Each faculty member received emails in advance requesting if and when the online survey tool could be administered during the first 10 minutes of their classes. The questionnaire was embedded as a Survey Monkey link into the main page of Bermuda College's learning management system called Moodle. At the agreed-on survey administration time students were asked to use their smartphones or the classroom computers to log on to Moodle's main page and click on the survey tool link to complete the online questionnaire.

The survey was designed to take less than eight minutes to complete. The data collection timeframe occurred between November 16 and December 2. A pre survey trial was completed by five random students to test the online questionnaire's flow, validity, question design and anticipated completion time.

Prior to the start of students gaining access to the survey tool students were asked to indicate their consent by the researchers to obtain access to their grades/cumulative GPA. After which students were directed to log on the course management system via their smartphones and complete the survey. Students were instructed that answering the first survey question with a "yes" or "no" response determined if they could or could not complete the balance of the questions. Giving consent by selecting the "yes" option allowed the balance of the survey questions to be answered. Negative responses prompted the survey tool to close and students were exposed to a short thank you message.

It was made clear to all potential respondents that access to student grades could only be obtained with their permission by providing their official Bermuda College email addresses for question two. It was also explained that no student names would be used in the research findings, just their cumulative GPAs for the respective semester. Both researchers attended all classes selected to deliver the aforementioned survey guidelines, provide a brief explanation about what the objective of the survey was and to offer any assistance to students if required during the questionnaire completion process.

\section{RESEARCH FINDINGS AND IMPLICATIONS}

A total of 257 students responded completed the online survey. This sample size represents approximately $40 \%$ of the entire student population. Hence, if collected randomly, the data would have had a $\pm 4.76 \%$ margin of error at the $95 \%$ confidence level.

In the data cleaning phase of the survey, it was noted that although some students had provided permission to access their grades, they failed to provide either their Bermuda College email address or an email address that could identify them. Further, some students were freshman taking noncredit courses and, as such, did not have a cumulative GPA. Both of these student data sets were eliminated from the 
study when making the GPA comparisons with excessive recreational smartphone use. Hence, only 181 students were usable for this section of the study.

The focus of this research was to determine if there was a correlation between smartphone usage and grade point average (GPA). If one were measuring the relationship between two continuous variables, the appropriate statistic to use would be the Pearson Correlation. In this study, only one of the variables were continuous, the GPA, while the other variables were categorical. As such the Pearson Correlation was not the appropriate statistic to use. When comparing continuous and categorical variables, the appropriate statistic to use is the ETA statistic. Like the Pearson Correlation, the ETA statistic measures the strength of a relationship between 0 and 1, with a statistic close to 0 showing no relationship, while a statistic closer to 1 showing a strong relationship.

Using the SPSS software package, there are two ways to calculate ETA. Under descriptive statistics, one can select cross tabulations and there is an option, under the Nominal by Interval tab, to select the ETA statistic. If the square of that value was calculated, ETA squared, it would provide a measurement of association of the dependent variable in the independent variable. The squared value is the same statistic that is provided in the General Linear Model, univariate, using the option of effect size. In this study, the General Linear Model was used to determine the level of association between smartphone usage and GPA. GPA was the independent variable as the hypothesis was the grades were dependent upon the level of smartphone usage.

Unlike other studies, which attempted to determine the number of hours spent on a phone, this study sought to determine if students use of their devices were excessive or not, allowing students themselves to interpret excessive. This was done as students tend to under report their level of usage. In either case, students self-reported their usage of smartphones.

This study found that there was a strong association between the level of smartphone usage and their impact on student grades. For recreational usage and GPA, the level of association using the ETA squared statistic, was 0.82 . For students that reported that they checked their smartphones frequently day and night, the statistic was similar at 0.82. The findings of this study can be compared to research performed at Kent University in 2014 of 500 undergraduate students, which found that, "students who used the smartphone more on a daily basis had a significantly lower college GPAs than similar students who used the phone less," (Lepp, Barkley \& Mansfield, 2015)

Clearly, there is a strong correlation between smartphone usage and its impact on grades. What this study did not determine is exactly what level of usage tends to impact grades. There are now apps such as available that accurately measure usage and thus a more precise measure of association could be obtained if, in a future study, sufficient numbers of students participated

Other pertinent data worth mentioning involves determining how many students indicated that they actually use their smartphones for educational purposes and if a majority or minority of students would most likely use their smartphones for educational purposes if encouraged to by faculty. A majority or $89 \%$ of students indicated that they are already using their devices for educational purposes. (See Table 1 on the next page). These results are similar to the $54.1 \%$ and $36.6 \%$ would very likely, or somewhat likely, use their smartphones for educational purposes if encouraged by faculty.

Just over half of the respondents indicated that they are often distracted by their smartphones while studying and a similar amount noted that they spent more time on their smartphones using social media platforms than studying for classes. (See Table 2 on the next page). A more alarming but very concerning statistic was the vast amount of students or $77.1 \%$ who said that they used their smartphones for recreational purposes while in class. Eleven students or 5.4\% confirmed how they excessively used their smartphones for recreational purposes during class. These findings place into question archaic and redundant smartphone polices that some faculty still include in their course outlines. For example, the following smartphone policy was retrieved from a faculty member's spring 2019 course outline at the authors' institution, located on their portal. "Students are not allowed to use cell phones during class and $\underline{\text { WILL }}$ be told to leave the class and not return for that particular session when observed using cell phones. If you are expecting a very important phone call or electronic message you may discreetly leave the room and return without disrupting the class or allowing the cell phone to be seen." 
TABLE 1

I USE MY SMARTPHONE FOR EDUCATIONAL PURPOSES

\begin{tabular}{llr|r|r|r}
\hline & & & & \multicolumn{2}{c}{$\begin{array}{c}\text { Cumulative } \\
\text { Percent }\end{array}$} \\
\hline \multirow{2}{*}{ Valid } & Frequency & Percent & Valid Percent & Per at all \\
\cline { 2 - 6 } & Seldom & 4 & 1.6 & 2.0 & 2.0 \\
\cline { 2 - 6 } & Often & 39 & 15.2 & 19.0 & 21.0 \\
\cline { 2 - 6 } & Excessively & 112 & 43.6 & 54.6 & 75.6 \\
\hline \multirow{2}{*}{ Missing } & System & 50 & 19.5 & 24.4 & 100.0 \\
\hline Total & & 205 & 79.8 & 100.0 & \\
\hline
\end{tabular}

TABLE 2

I SPEND MORE TIME ON MY SMARTPHONE USING SOCIAL MEDIA PLATFORMS THAN STUDYING FOR MY CLASSES

\begin{tabular}{llr|r|r|r}
\hline & & & & \multicolumn{2}{c}{$\begin{array}{c}\text { Cumulative } \\
\text { Percent }\end{array}$} \\
\hline \multirow{2}{*}{ Valid } & Frequency & Percent & Valid Percent & 1.0 & 1.0 \\
\cline { 2 - 6 } & Not applicable & 2 & .8 & 6.3 & 7.3 \\
\cline { 2 - 6 } & Strongly Disagree & 13 & 5.1 & 20.0 & 27.3 \\
\cline { 2 - 6 } & Disagree & 41 & 16.0 & 22.9 & 50.2 \\
\cline { 2 - 6 } & Neither Agree nor Disagree & 47 & 18.3 & 35.1 & 85.4 \\
\hline & Strongly Agree & 72 & 28.0 & 14.6 & 100.0 \\
\hline Missing & System & 30 & 11.7 & 100.0 & \\
\hline Total & & 205 & 79.8 & & \\
\hline
\end{tabular}

The smartphone usage relationship factor between other students and faculty was weak with an ETA value of 0.057 for students and 0.016 for lecturers (See Tables 3 and 4). These findings imply that smartphone use, whether it be excessive or not does not affect student to student and/or student to faculty relationships. This conclusion seem reasonable as smartphones are primarily used to stay in close contact with friends and family, but not with fellow students without a previous relationship. Similarly, due to personal privacy preferences, student to teacher smartphone contact would likely be minimal under most circumstances. Therefore, the level of smartphone use would have little bearing on that relationship. 
TABLE 3

SMARTPHONE USAGE AFFECTS MY RELATIONSHIP WITH MY FELLOW STUDENTS

\begin{tabular}{|c|c|c|c|c|c|c|}
\hline \multicolumn{7}{|c|}{ Tests Between-Subjects Effects } \\
\hline \multirow{2}{*}{\begin{tabular}{|c|}
$\begin{array}{c}\text { Dependent } \\
\text { Variable: }\end{array}$ \\
Source
\end{tabular}} & \multirow{2}{*}{\begin{tabular}{|c|}
$\begin{array}{c}\text { Use my phone for } \\
\text { recreational activities }\end{array}$ \\
Type III Sum of \\
Squares
\end{tabular}} & \multicolumn{3}{|c|}{ Affects interaction with fellow students } & \multirow[b]{2}{*}{ Sig. } & \multirow[b]{2}{*}{$\begin{array}{l}\text { Partial Eta } \\
\text { Squared }\end{array}$} \\
\hline & & df & Mean Square & $\mathrm{F}$ & & \\
\hline Corrected Model & $5.221^{\mathrm{a}}$ & 4 & 1.305 & 2.637 & .036 & .057 \\
\hline Intercept & 596.684 & 1 & 596.684 & 1205.555 & .000 & .873 \\
\hline q0006_0003 & 5.221 & 4 & 1.305 & 2.637 & .036 & .057 \\
\hline Error & 87.110 & 176 & .495 & & & \\
\hline Total & 773.000 & 181 & & & & \\
\hline Corrected Total & 92.331 & 180 & & & & \\
\hline $\begin{array}{l}\text { a. R Squared }=.0 \\
\text { Squared }=.035 \text { ) }\end{array}$ & (Adjusted R & & & & & \\
\hline
\end{tabular}

TABLE 4

SMARTPHONE USAGE AFFECTS MY RELATIONSHIP WITH MY LECTURERS

\begin{tabular}{|l|r|r|r|r|r|r|}
\hline Tests of Between-Subjects Effects & & & \\
\hline Dependent Variable: & $\begin{array}{c}\text { Use my phone for } \\
\text { recreational } \\
\text { activities }\end{array}$ & \multicolumn{2}{|l|}{$\begin{array}{l}\text { Affects interaction with } \\
\text { lectures }\end{array}$} \\
\hline Source & $\begin{array}{c}\text { Type III Sum of } \\
\text { Squares }\end{array}$ & df & $\begin{array}{c}\text { Mean } \\
\text { Square }\end{array}$ & F & Sig. & $\begin{array}{c}\text { Partial Eta } \\
\text { Squared }\end{array}$ \\
\hline Corrected Model & 1.468 & 4 & .367 & .711 & .585 & .016 \\
\hline Intercept & 475.857 & 1 & 475.857 & 921.723 & .000 & .840 \\
\hline q0006_0004 & 1.468 & 4 & .367 & .711 & .585 & .016 \\
\hline Error & 90.863 & 176 & .516 & & & \\
\hline Total & 773.000 & 181 & & & & \\
\hline Corrected Total & 92.331 & 180 & & & & \\
\hline $\begin{array}{l}\text { a. } \text { R Squared }=.016 \text { (Adjusted R Squared } \\
=-.006)\end{array}$ & & & & & & \\
\hline
\end{tabular}




\section{CONCLUSION}

Smartphone devices not only continue to play a pivotal role in the lives of most people but are also here to stay. Moreover, institutions of higher learning have undeniably been, and will continue to be transformed by how students remain dependent on these devices. Our reliance on smartphones affect how we communicate, travel, purchase goods and services, manage our finances, time, socialize and even how students learn.

Smartphones have made it much easier and faster to obtain vast amounts of relevant knowledge that can be applied pre, during, and post the learning process. Data obtained from this and other relative research highlights how smartphones, if endorsed correctly by faculty, can improve the learning process, increase student-to-student and faculty-to-student interactions. These devices can also give students the opportunity to acquire real-time information about concepts being debated during class or an important learning objective that might require an alternative perspective. The benefits associated with in-class smartphone use are persuasively outlined by Marcus Hennessy when he stated in a Lesson Plans by Teachers for Teachers online article, that "Smartphones give students a wealth of creative options to enhance the classroom experience, including:

- Access to the internet for research and referencing

- Access to e-mail

- The ability to snap a picture of the day's homework assignment scribbled on a whiteboard or take a short video of a key lecture moment

- Apps like Evernote to store, catalog, and annotate smartphone photos

- Apps like ResponseWare that convert smartphones into classroom "clickers" that can answer multiple-choice questions

- Recording lectures with Voice Memo and other third-party note-taking apps

- Using QR codes to find relevant websites with a simple click

- Keeping track of schedules and dates." (Hennessy, 2018)

Over the past decade a plethora of engaging technology-based teaching and learning platforms have revolutionized how and where course content gets delivered. Consequently, faculty should consider adopting creative smartphone-friendly content delivery options, which are designed to shift unproductive recreational time students spend on smartphones into more productive learner-centric time. Likewise, faculty will most likely benefit from embracing the wisdom associated with encouraging "smartphone dependent" students to use their devices so that they can experience a more personalized learning experience while in or out of the classroom.

An abundance of free, engaging, virtual learning platforms such as: Kahootit.com, H5P, FlipGrid, Packback, Remind.com, ClassDojo.com, Inspiration.com Zoom.com, Quizlet.com, Poll Everywhere.com, and Nearpod can be used to facilitate and encourage mobile learning. Moreover, smartphones can be used to create an emerging and active learning environment that encourages virtual knowledge gathering and sharing.

Outside of the brick and mortar classrooms, students can use their smartphones to not only stay connected with faculty but also continue learning in a virtual "anywhere, anytime" environment. A classic example of this approach was recently featured in the New York Times when Ohio State Journalism Professor Nicole Kraft proclaimed that she, "Takes attendance for her class via Twitter, posts coursework on the instant-messaging app Slack, and holds office hours on the video-conferencing app Zoom at 10:00 p.m., because that is when they have questions." (Pappano, August 2018) A study by Odem validates this unique digital driven approach by concluding that, "In mobile learning, students access course content when and where they want." (Odem, 2016)

The results from this study clearly indicate that students prefer more faculty adopt teaching practices that are infused with higher amounts of technology so that increased amounts of educationally driven smartphones usages occurs in the classroom instead of recreational. According to Odem, specific smartphone guidelines must be established detailing when smartphones can and cannot be used during 
class. Also, clear distinctions must be made to determine appropriate versus inappropriate smartphone use during class.

This study also deduced that smartphones distract students from learning due to the excessive time they spent using online social networking platforms, texting, gaming and streaming videos. With an abundance of entertainment options available on smartphones, high users, with some exceptions, are most likely not studying as much as they need to. This constant connection with their smartphones is unfortunately for recreational instead of educational purposes.

Maybe it is time to let the archaic teaching delivery methods die. Those faculty who provide creative technology-based teaching techniques and platforms that are not only appealing but also capable of delivering engaging and immerging learning experiences will most likely not have to worry about declining enrollment numbers. Albeit, technology is not a panacea, but when utilized correctly it can certainly do more good than harm when attempting to deliver course content that remains appealing to digital natives.

The dilemma faced by many higher learning institutions remains the same. What steps should be taken to strategically convert excessive recreational smartphone use into productive and engaging student learning opportunities? Can the implementation of a digital strategic plan create a paradigm shift that swings the pendulum away from excessive recreational smartphone usage by students to excessive educational smartphone usage because, as mentioned earlier, students are going to use their beloved mobile devices even if faculty do not.

Finally, it must be noted that data collected for this study involved a self-reflective variable and future studies may well involve students using software such as "Moment" to measure exactly how much time they spend on their smartphones and identify which apps are being used the most. Thus, it would be able to quantify exactly how much time students spent on their smartphones and the particular recreational apps being used. This process will replace the self-reflective variable with a numerical one when determining the correlations with educational outcomes.

\section{STUDY LIMITATIONS}

It must be noted that this study acquired self-reflective data and did not examine the correlation between the actual amount of recreational time students spent on smartphones and overall GPA results. However, the authors plan to conduct a controlled follow-up study, which requires students to install smartphone use tracking software such as "Moment" that is capable of calculating the actual amounts of screen time activity, most and least frequently used apps, and smartphone pick-ups per day. Similarly, important data such as time spent on social media platforms and popular gamming websites will be analyzed to determine if these activities have or do not have a significant impact on overall academic outcomes.

This process will replace the self-reflective variable with a numerical one when determining the correlations with educational outcomes. Consequently, the authors will be able to conduct more rigorous statistical tests that will better ascertain the degree to which student grades are affected by excessive recreational smartphone use. 


\section{REFERENCES}

Aldunate, R., \& M. Nussbaum. (2012). Teacher Adoption of Technology, Computers in Human Behaviour. Retrieved September 21, 2018, from http://www.elsevier.com/locate/comphumbeh

Anderson, M., \& Jiang, J. (2018). Teens, Social Media \& Technology 2018. Pew Research Center, Internet and Technology. Retrieved November 15, 2018, from http://www.pewinternet.org/2018/05/31/teens-social-media-technology-2018/

Barkley, E. (2010). Student Engagement Techniques: A handbook for College Faculty. San Francisco, CA: John Wiley \& Son, Inc., Jossey-Bass.

Chickering, W., \& Ehrmann, C. (1996). Implementing the Seven Principles: Technology as a Lever. American Association for Higher Education, October, 3-6.

De Shields, S. (2016). Impacts of Technology in the Learning Process. Voices in Education Student Success A National Focus Journal of Bermuda College, 2(1), 49 - 59.

Doidge, N. (2007). The Brain that Changes Itself: Stores of Personal Triumph from the Frontiers of Brain Science. Penguin Books Ltd.

Freeman, S., Eddy, S., McDonough, M., Smith, M., Okoroafor, N., Jordt, H., \& Wenderoth, M. P. (2014). Active Learning Increases Student Performance in Science, Engineering, and Mathematics. Proceedings of the National Academy of Sciences of the United States of America. Retrieved November 27, 2018, from https://www.researchgate.net/publication/262267588_Active_Learning_Increases_Student_Perfor mance_in_Science_Engineering_and_Mathematics.

Halaweh, M. (2017). Using Mobile Technology in the Classroom: A Reflection Based on Teaching Experience in UAE. TechTrends. Linking Research \& Practice to Improve Learning, 61(3), 218 222.

Hennessy, M. A. (2018). Smartphone Use in the Classroom: More Advantages than Risk, Using Smartphones (and other PDAs) in Class, These Days, it's Cool. Lesson Plans Page,

Lessons Plans by Teachers for Teachers. Retrieved March 18, 2019, from http://lessonplanspage.com/using-smartphones-and-other-pdas-in-class-these-days-its-cool/

Jobs, S. (2007). Introducing the first iPhone speech.

Kim, J., Lynn, I., \& Altman, J. (2013). Adapting Smartphones as Leaning Technology in a Korean University. Journal of Integrated Design and Process Sciences, 17(1), 5.

Lepp, A., Barkley, J., \& Mansfield, E. (2015, March 5). As College Students'Smartphone Use Goes Up, Students' Smarts in the Classroom Go Down. Retrieved November 19, 2018, from https://www.kent.edu/kent/news/college-students\%E2\%80\%99-smartphone-use-goesstudents\% E2\%80\%99-smarts-classroom-go-down.

Lepp, A., Barkley. J.E., \& Karpinski. A.C. (2015, February 19). The Relationship between Cell Phone Use and Academic Performance in a Sample of U.S. College Student. Sage Open. Retrieved November 15, 2018, from https://journals.sagepub.com/doi/10.1177/2158244015573169

Lepp, A., Barkley. J.E., \& Karpinski. A.C. (2013, December 6). Frequent Cell Phone Use Linked to Anxiety, Lower Grades, Reduced Happiness in Students. Science Daily. Retrieved November 15, 2018, from www.sciencedaily.com/releases/2013/12/13120612445.htm

Lieberman, M. (2019). Students Are Using Mobile Even If You Aren't. [Electronic version]/ Insider Higher ED. Retrieved February 28, 2019, from https://www.insidehighered.com/digitallearning/article/2019/02/27/mobile-devices-transform-classroom-experiences-and.

Martinez, M. (2014). Deeper Learning: The New Normal. AdvanceED. Retrieved September 28, 2018, from http:// www.advanc-ed.org/source/deeper-learning-new-normal

Next Generation Learning Spaces. (2019, February 25-27). Retrieved February 25, 2019, from https://higheredlearningspaces.iqpc.com/downloads/how-technology-is-taking-higher-edlearning-spaces-to-new-heights?-ty-m

Odom, D. (2016). Teaching with Smartphones in the Higher Education Classroom. Journal of Youth Ministry, 14(2), 6-15. 
Pappand, L. (2018). The iGen Shift: Colleges are Changing to Reach the Next Generation. The New York Times. Retrieved December 15, 2018, from https://www.nytimes.com/2018/08/02/education/learning/generationz-igen-students-colleges.html

Pirani, J., \& Sheehan, M. (2009). Spreading the Word: Messaging and Communication in Higher Education-Key Findings. Boulder, CO: EDUCAUSE Center for Applied Research.

Quadri, D. (2013). Foundations of Effective Technology Integration: Best Practices in Teaching. Career Advancement Academy Teaching Consortium pre-conference session. International Council of Hotel, Restaurant and Institutional Education Conference, St Louis, Missouri, 24-27 July.

Richtel, M. (2017, March 13). Are Teenagers Replacing Drugs with Smartphones? [Electronic version]/ The New York Times. Retrieved November 24, 2018, from https:/www.nytimes.com/2017/03/13/health/teenagers-drugs smartphones.html?rref $=$ collection $\% 2$ Fsectioncollection $\% 2$ Fscience\&action=click\&contentCollec tion $=$ science\&region $=$ stream $\&$ module $=$ inline $\&$ version $=1$ atest $\&$ contentPlacement $=6 \&$ pgtype $=$ sect ionfront

Roach, R. (2010). Digital Remix. Diverse: Issues in Higher Education, 27(3), 10-12.

Rudi, A. (2011). The Digital Natives are Restless. eSchool New; Daily Tech News \& Innovation. Retrieved October 15, 2018, from http://www.eschoolnews.com/2011/08/22/the-digital-nativesare-restless/

Sample size calculator. (n.d.). Retrieved March 18, 2018, from https://www.checkmarket.com/samplesize-calculator/

Shooriabi, M., \& Gilavand, A. (2017). Investigating the Use of Smartphones for Learning Purposes by Iranian Dental Students. Middle East Journal of Family Medicine, 15(7), 108-113. Retrieved November 26, 2018, from http://search.ebscohost.com/login.aspx?direct=true \&db=a9h\&AN=124945657\&site=ehost-live

Twenge, J.M. (2017, September). Have Smartphones Destroyed a Generation? More comfortable online than out partying, post-Millennials are safer, physically, than adolescents have ever been. But they're on the brink of a mental-health crisis. The Atlantic Daily online. Retrieved November 22, 2018, from https://www.theatlantic.com/magazine/archive/2017/09/has-the-smartphonedestroyed-a-generation/534198/ 